\title{
A magyar középiskolások pénzügyi kultúrájának vizsgálata az elmúlt 10 évben Econventio-teszt alapján
}

\author{
Kovács Péter \\ Szegedi Tudományegyetem \\ kovacs.peter@eco.u-szeged.hu \\ Kuruczleki Éva \\ Szegedi Tudományegyetem \\ kuruczleki.eva@eco.u-szeged.hu \\ Rácz Tamás Attila \\ Szegedi Tudományegyetem \\ racz.tamas@eco.u-szeged.hu \\ Lipták Lilla \\ Szegedi Tudományegyetem \\ liptak.lilla@eco.u-szeged.hu
}

\begin{abstract}
Összefoglaló
Az Econventio Egyesület a Szegedi Tudományegyetem Gazdaságtudományi Karával 2011 óta fejleszti a középiskolások pénzügyi kultúráját. Tanulmányunkban az elmúlt 10 év felméréseinek fóbb megállapításait foglaljuk össze, amely összesen 110 ezer tesztkitöltésre épül. Felméréseink szerint a középiskolások kevés és felületes pénzügyi ismerettel rendelkeznek. A pénzügyi tudás pozitív kapcsolatban áll az előre gondolkodás időtávjával, az öngondoskodásról való gondolkodásról, a pénzügyek iránt tanúsított hozzállással. A digitális pénzügyi információforrások szerepének növekedése mellett, a középiskolások pénzügyi ismereteiket legfőképpen az otthonlátottakból merítik, ez negatívan hat a teszteredményekre, ugyanakkor a pénzügyi ismeretek oktatásának pozitív hatása van a diákok pénzügyi tudására. Az életkor, a tapasztalatok növekedésével a pénzügyi tudásszint nő, különösen a munkaerőpiaci, hitelezési, biztosítási kérdések esetén, ugyanakkor a felnőtteknek és a középiskolásoknak is ugyanazok a kérdéskörök jelentenek nagyobb nehézséget: százalékszámítás, a kamatos kamat számítása, a legalább, legfeljebb kifejezések kezelése, különböző ajánlatok összehasonlítása.
\end{abstract}

KulcsszavaK: pénzügyi kultúra, Econventio-teszt, pénzügyi tudatosság

JEL-кódoк: G53, A20, D14, H24, J32

DOI: https://doi.org/10.35551/PSZ_2021_2_1 
A fiatalok pénzügyi kultúrájának fejlesztése kulcsfontossággal bír a felnőttkori pénzügyi stabilitás megteremtésében, hiszen ebben a korban még sokkal fogékonyabbak a fejlesztések iránt és azok a hiányosságok, melyek serdülökorban jelentkeznek felnőttkorban már nehezebben pótolhatók. Az Econventio Kerekasztal Közhasznú Egyesület a Szegedi Tudományegyetem Gazdaságtudományi Karával 2011-ben kezdte vizsgálni és fejleszteni a hazai középiskolások pénzügyi kultúráját. Ebben a tanulmányban az elmúlt 10 év felméréseinek tapasztalatait, fóbb megállapításait foglaljuk össze. A téma aktualitását az évforduló mellett több tényező is indokolja, mint például a világjárvány és a mellette kibontakozó gazdasági válság, amely a hazai családok pénzügyi stressztűrőképességét is próbára teszi, illetve folyamatosan megjelenő új, digitális pénzügyi szolgáltatások, amelyek alapjaiban változtatják meg a pénzügyi szokásainkat. Az Econventio Egyesület Magyarországon a legnagyobb eléréssel rendelkező pénzügyi felmérésekkel és képzésekkel rendelkező szervezetek közé tartozik. Az elmúlt évek során több mint 110 ezer fö vett részt az egyesület pénzügyikultúra-felméréseiben és fejlesztési programjaiban. A résztvevők nagy száma miatt az eredmények részletes képet adnak a hazai középiskolások pénzügyi tudásáról és szokásairól (Németh, Vargha, Domonkos, 2020a). Vizsgálatunk fö célcsoportja a középiskolás diákok, akiknek a pénzügyek dinamikusan fejlődő világában nemcsak a különböző digitális pénzügyi szolgáltatások útvesztőjében kell elnavigálniuk, hanem fel kell készülniük a jövőjüket meghatározó pénzügyi döntések meghozatalára. Ezek a fiatalok már a számítógépek, telekommunikációs eszközök és az internet korában születtek, életüket végigkísérte a technológia, már egészen kicsi gyermekkoruktól. Ez a korábbi generációkhoz képest egyrészt jelentősen átalakította a világról alkotott képüket, és kihatással volt a pénzügyi kultúrájuk fejlődésére is, másrészt a pénzügyi szolgáltatások egyre szé- lesebb köre áll rendelkezésükre, amelyből egyre nagyobb kihívást jelent a számukra megfelelő instrumentumok kiválasztása. Tanulmányunk az Econventio középiskolások pénzügyikultúrafelméréseinek főbb eredményeit, megállapításait mutatja be az elmúlt tíz évből.

\section{SZAKIRODALMI ÁTTEKINTÉS}

A pénzügyi kultúra minden korosztályt érint, hiszen a mindennapok során pénzügyi döntéseket kell hoznunk, illetve egy család, háztartás tagjaként a mindennapi pénzügyi döntések jelentősen befolyásolják az életünket. Emellett a médiában nap mint nap jelennek meg pénzügyi, gazdasági vonatkozású hírek, anyagok, amelyek megértéséhez megfelelő mértékű pénzügyi, gazdasági ismeretekre van szükségünk.

A felnőtt lakosság nagy része sem iskolai tanulmányai során, sem a későbbiekben nem tanult pénzügyi, gazdasági ismereteket (Horváthné, Széles, 2014), illetve, ha tanult is, több, ma létező pénzügyi termék még nem létezett akkor, amikor ilyen jellegü tanulmányokat folytattak, hiszen ahogyan azt Béres és Huzdik (2012) is megfogalmazta, a pénzügyi piacok fejlődése gyorsabb az egyének pénzügyi kultúrájának gyarapodásánál. A szakadék csökkentéséhez a pénzügyi kultúra folyamatos fejlesztésére van szükség, amely egyértelműen oktatással, illetve gyakorlati ismereteken keresztül érhető el.

\section{A pénzügyi kultúra definíciója}

Bár tanulmányunknak nem célja a pénzügyi kultúra definíciójának részletes bemutatása, vizsgálati modellünk alapjaihoz elengedhetetlen megemlíteni a legfontosabb definíciókat a témában. A pénzügyi kultúra leggyakrabban említett fogalma az OECD szerint: „A pénzügyi kultúra a tudatosság, ismeretek, készségek, attitüdök és viselkedések kombinációja, amelyek- 
re szükség van a megalapozott pénzügyi döntések meghozatalához és végsö soron az egyéni pénzügyi jólét eléréséhez" (Atkinson, Messy, 2012, p. 14). A meghatározás és az általa leírt döntési folyamat (az információk gyűjtésétől, azok rendszerezésén át a döntés meghozataláig) összetettsége az empirikus vizsgálatokban komplex, több területre kiterjedő megközelítést igényel.

A koncepcionális meghatározásba beleilleszthető a Magyar Nemzeti Bank 2008-ban megjelent definíciója, amely szerint a pénzügyi kultúra nem más, mint „a pénzügyi ismeretek és készségek olyan szintje, amelynek segitségével az egyének képesek a tudatos és körültekintö döntéseikhez szükséges alapvetö pénzügyi információkat azonositani, majd azok megszerzése után azokat értelmezni, és ez alapján döntést hozni, felmérve döntésük lehetséges jövöbeni pénzügyi, illetve egyéb következményeit." (MNB-PSZÁF, 2008,1 .) Tehát az egyének „képesek felmérni a kockázatot, valamint a döntésükben rejlö bizonytalanságot" (Huzdik, Béres, Németh, 2014, 476. oldal). Kiemelendő a megfogalmazásból a döntések eredménye, amely néhány korábban említett definícióból hiányzott.

A pénzügyi kultúra fogalmának összetettsége miatt ennek vizsgálatára komplex modellek alkalmazása javasolt. A szakirodalom a vizsgálandó részterületekben nagyrészt egyetért, ugyanakkor az alkalmazott mérőeszközök nem egységesek. Vannak olyan kutatások, amelyek kevesebb kérdéskört vizsgálnak, mert inkább bizonyos kérdéscsoportokra szeretnének koncentrálni. Ahhoz, hogy komplex kép alakuljon ki a pénzügyi kultúráról, érdemes a témakörök nagy részét lefedni.

\section{Pénzügyi kultúra \\ a felnőtt lakosság körében}

A középiskolások pénzügyi kultúrájának vizsgálata előtt érdemes kitérnünk szüleik, azaz a felnőtt lakosság pénzügyi kultúrájának sajátos- ságaira, mivel ahogy azt a későbbiekben is látni fogjuk, a mai fiatalok pénzügyi kultúráját nagyban határozza meg az, amit otthon tapasztalnak, hiszen többségük föként szüleitől és az otthonukban látottakból szerzik pénzügyekkel kapcsolatos ismereteiket (OECD, 2020a).

A lakosság körében végzett hazai kutatások (például Botos et al., 2012; Béres, Huzdik, 2012; Huzdik, Béres, Németh, 2014; Kovács, Kuruczleki, 2017; Zsótér, Németh, Luksander, 2017; Németh, Zsótér, Béres, 2020b) eredményei a pénzügyi ismeretek alkalmazásának viszonylag alacsony színvonaláról árulkodnak.

Az S\&P (Klapper, Lusardi, Oudheusden, 2015) 144 országban végzett felmérése szerint a válaszadók 65 százaléka, míg a magyarok 46 százaléka pénzügyi analfabéta. A felmérés során négy témakörben (diverzifikáció, kamatszámítás, kamatos kamat, infláció) öt kérdést tesznek fel, és azokat tekintik pénzügyileg jártasnak, akik legalább három kérdésre helyesen válaszolnak. Ezzel az eredménnyel Magyarország a 19. legjobb helyre került a vizsgált országok közül. Világviszonylatban a felmérésen a résztvevők 35 százaléka tekinthető pénzügyileg jártasnak, a férfiak körében a pénzügyileg jártasok aránya 10 százalékponttal magasabb, mint a nők körében. A nemek közötti eltérés világviszonylatban is jelen van, nemcsak az S\&P felmérése, de számos más nemzetközi felmérés is alátámasztja, hogy a férfiak általában tájékozottabbak, így szignifikánsan jobb eredményeket érnek el a nőknél, országtól és gazdasági-társadalmi háttértől függetlenül. Ezzel párhuzamosan, bár a nők kis mértékben alulmaradnak a férfiakhoz képest a pénzügyi tudásteszteken, azokban az országokban, ahol magasabb a pénzügyileg tájékozott férfiak aránya, ott a nők körében is magasabb a pénzügyileg tájékozottak aránya más országokhoz képest (Hasler, Lusardi, 2017). Ez a kép Magyarországon nem ennyire egyértelmű az $\mathrm{S} \& \mathrm{P}$ mérése szerint: míg a férfiak 53, addig a nők 55 százaléka tekinthető pénzügyileg jártasnak 
a felmérés szerint, amely eredmény valószínüleg a vizsgálatban alkalmazott definíciónak és a kevés kérdésnek is köszönhető.

$\mathrm{Az}$ OECD legfrissebb, 2018-as felmérésében 26 országban közel 126 ezer fó bevonásával vizsgálta a felnőtt lakosság pénzügyi tudását, készségeit és attitűdjeit, köztük Magyarországon is. A felmérés a magyar lakosság alacsony pénzügyi kultúra szintjéről számol be, a résztvevők a tudást vizsgáló kérdések átlagosan 61 százalékát válaszolták meg helyesen. (OECD, 2016; OECD, 2020a). A legmagasabb átlagos eredménnyel a Hong Kong-i felnőttek rendelkeznek (71 százalék), míg a legalacsonyabb átlagos eredmény Olaszországra jellemző (53 százalék). Tudásukat tekintve a felmérésben résztvevőknek a legnagyobb gondot a kamatos kamat számítása jelentette, az átlaghoz képest azonban lényegesen jobban teljesítettek az egyszerű kamatszámítás és az infláció témaköreiben, amely mintázat egyébként a korábbi évekre is jellemző volt. A 2015-ös OECD-felmérésben és a 2014-es Standard\&Poor’s által végzett felmérésben is ugyanezeken a területeken teljesítettek kiemelten jól a magyar válaszadók (OECD, 2016; Klapper, Lusardi, Oudheusden, 2015). Pénzügyi viselkedésüket tekintve a magyar felnőttek a második legroszszabb eredményt érték el, éppen csak megelőzve Olaszországot és lemaradva Montenegrótól. Attitüdjüket tekintve viszont épp ellenkezöleg, a legjobbak között teljesítettek a magyarok, azonos átlagpontszámot elérve, mint Indonézia és alig elmaradva Thaiföld és Szlovénia eredményétől a harmadik legmagasabb átlagpontszámot érték el (OECD, 2020a).

A 2018-as OECD-felmérés új elemként vezeti be a mérésben a pénzügyi stressztűrő képesség fogalmát: ez magában foglalja többek között a pénzügyi tervezést, a pénzügyi helyzet rendszeres figyelemmel kísérését, az adósságkezelést és csőddel kapcsolatos tudatosságot, illetve a tartalékok, „pénzügyi párna” képzését. A magyar felnőttek a legtöbb területen igen alacsony stressztűrő képességről számolhatnak be, azaz elmaradnak az átlagtól, de ami a legérdekesebb, hogy a felmérésben részt vevő magyar felnőttek 34,8 százaléka mindössze egy hétre elegendő pénzügyi tartalékkal rendelkeznek, amennyiben jövedelmük megszűnne. Ez a hosszú távú szemlélet és a megtakarítások hiányára vagy nem megfelelő kezelésére is utalhat a felnőtt lakosság körében. (Klapper, Lusardi, 2020; Lusardi, Hasler, Yakoboski, 2020; OECD, 2020a).

Fontos egy további fogalmat bemutatni, amely egyre inkább teret kap a nemzetközi szakirodalomban is. Ez a fogalom a pénzügyi sérülékenység (Németh, Zsótér, Béres, 2020b), amellyel azért fontos foglalkozni, hiszen a sérülékenység negatívan hat, nemcsak a háztartások és egyének jövedelmi helyzetére, de azon keresztül összességében életszínvonalukra is. A pénzügyi sérülékenység számos demográfiai tényezővel kapcsolatban állhat, ahogy azt Németh és szerzötársai (2020b) részletesen bemutatták: a nemek tekintetében a nők sérülékenyebbek, míg az iskolai végzettség szempontjából az alacsonyabb iskolai végzettségűek, jövedelmüket tekintve pedig az alacsonyabb jövedelműek tekinthetők sérülékenyebb csoportoknak. Ez összecseng több nemzetközi felmérés eredményével, illetve ezek az állítások általában Magyarország esetében is megfigyelhetők (Klapper, Lusardi, Oudheusden, 2015; Németh, Zsótér, Béres, 2020b).

\section{A mai középiskolások pénzügyi kultúrája}

Az OECD 2015-ben megalkotta a fiatalok pénzügyi kultúrájának keretrendszerét, amely a 15 és 18 év közötti fiatalok vonatkozásában fogalmazza meg a pénzügyi kultúrát meghatározó legfontosabb kompetenciákat, figyelembe véve életkori sajátosságaikat, folyamatosan táguló látókörüket és a felsőoktatásra, a munka- 
erőpiacra, valamint az önálló életre való felkészülésüket. A keretrendszer négy témakörben fogalmazza meg a legfontosabb tudás, attitűd és viselkedési elemeket, ezek a pénz és a gazdasági tranzakciók, a pénzügyek tervezése és kezelése, a kockázatok kezelése, illetve a pénzügyi környezet. Ezen témakörökön belül számos témát határoznak meg, amely egy fiatal számára fontos lehet, ilyenek például a különböző jövedelemmel és pénzeszközökkel kapcsolatos témák, a hosszú távú pénzügyi orientáció vagy akár az oktatás és a folyamatos önfejlesztés fontossága (OECD, 2015).

A háromévente megrendezésre kerülő nemzetközi tanulói teljesítménymérő programjuk, azaz a PISA-felmérés részeként 2018-ban már harmadik alkalommal mérték fel a 15 éves fiatalok pénzügyi kompetenciáit, és bár eddig a magyar fiatalok nem vettek részt a felmérés ezen moduljában (mivel a pénzügyi-gazdasági modulban való részvétel önkéntes volt), a felmérés alapján képet kaphatunk a mai fiatalok pénzügyi kompetenciáiról. A legfrissebb (2018-as), 20 ország körülbelül 117 ezer középiskolásának bevonásával készült PISAfelmérés eredményei azt mutatják, hogy az egyes országok középiskolásainak pénzügyi tudása között igen számottevő különbségek fedezhetők fel. A gazdasági-társadalmi szempontból előnyösebb helyzetben levő országok (például Észtország vagy Kanada) diákjai jelentősen magasabb pontszámokat értek el, mint a hátrányosabb helyzetű országok (mint például Indonézia vagy Grúzia) diákjai. Mindez többek között - az országok fejlettségének, az ott elérhető pénzügyi szolgáltatások körének és az oktatás színvonalának is betudható, s a különbségek nemcsak az egyes országok között, hanem az országokon belül is megfigyelhetők (OECD, 2020b). Az eredmények alapján a fiatalok föleg a szüleiktől szerzik pénzügyekkel kapcsolatos ismereteiket, azonban alig elhanyagolható hozzájuk képest az internet szerepe. A digitális pénzügyek terén összességében nem teljesítenek kiemelkedően, illetve nem túl magabiztosak, amikor a digitális térben kell pénzügyeikről dönteni, vagy szolgáltatásokat igénybe venni. Azok a fiatalok, akik attitűdjüket tekintve pozitívabban állnak a digitális pénzügyekhez, összességében jobban teljesítettek a felmérés pénzügyi-gazdasági moduljában, tehát a digitális pénzügyek iránti nyitottság további tájékozódással és magasabb tudásszinttel társulhat (OECD, 2020b).

A középiskolás fiatalok pénzügyi kultúráját az OECD felmérései mellett számos tanulmány vizsgálja. Mindezen felmérések közös eleme, hogy a fiatalokra általában a pénzügyi kultúra rendkívül alacsony szintje jellemző (Lusardi, Mitchell, Curto, 2010), a felnőtteknél jelentősen alacsonyabb pénzügyi tudás és tudatosság jellemzi őket, amely az oktatás hiányosságai mellett fiatal koruknak és ebből fakadóan a pénzügyi tapasztalatok hiányának is betudható. Bár fiatal korukból adódóan sok területen nem ismerjük pénzügyi készségeiket és viselkedésüket (Harputlu, Kendirli, 2019; Mondres, 2019), tudásukat tekintve igen jelentős hiányosságok jellemzők rájuk, és bár igen alacsony tudással rendelkeznek pénzügyeiket illetően, felismerik és elismerik hiányosságaikat, aggódnak pénzügyeik jövője miatt (Beck, Garris, 2019; Mondres, 2019). Tisztában vannak hiányosságaikkal és nyitottak pénzügyi kultúrájuk fejlesztése iránt, azonban nem feltétlenül a hagyományos iskolarendszerü oktatás keretein belül, hanem például online képzéseken (Beck, Garris, 2019).

\section{A pénzügyi kultúra oktatásának szerepe a középiskolában}

A fiatalok pénzügyi kultúrájának fejlesztése akár az iskolarendszerü képzések körében, akár különálló foglalkozások keretében egyre fontosabb szerepet játszik nemzetközi és hazai szinten egyaránt. Amagir és szerzőtár- 
sai (2017) felmérésében számos ország (például USA, Olaszország, Spanyolország, Ghána, Dél-Afrikai Köztársaság stb.) kifejezetten gyerekeket, középiskolás diákokat és fiatal felnőtteket (egyetemistákat) célzó pénzügyikultúra-fejlesztő programjainak hatékonyságát vizsgálták. Eredményeik rámutattak, hogy a képzések fontosak, hiszen többségében jelentősen növelték a fiatalok pénzügyi ismereteinek szintjét. Bár viselkedésükre és attitűdjeikre kevésbé hatottak hosszú távon, mint az otthon tapasztaltak, a képzések mégis hozzájárulnak ahhoz, hogy a fiatalok felelösebb állampolgárokká váljanak azáltal, hogy pénzügyeikben is tudatosabbak. Ezt azonosítják a szerzők az „economic citizenship” fogalmával, amely már nemcsak az egyén szintjén rendelkezik jelentöséggel, hanem fontos nemzetgazdasági következményekkel is járhat. Eredményeik szerint a legtöbb országban közel azonos témák kerülnek elő a fiatalok pénzügyikultúra-képzésein, ilyenek a személyes pénzügyek menedzselése, megtakarítások és befektetések, banki szolgáltatások, munkával és jövedelemmel kapcsolatos témakörök, sőt a nyugdíj és öngondoskodás témaköre is előkerül már egészen fiatalok esetén is. A vizsgálat egy további fontos eredménye, hogy a nemek közti eltérések már egészen fiatalon megmutatkoznak, a legtöbb képzés előtt kitöltött pénzügyi tudásteszten a fiúk általában szignifikánsan jobban teljesítettek, mint a lányok, pusztán abból adódóan, hogy tizenéves korukban a lányok egyszerűen általánosságban is kevésbé érdekeltek a pénzügyekben, mint a fiúk, azonban a képzések pont az ő esetükben hatásosabbak voltak, jelentősen javultak pénzügyi ismereteik és érdeklődőbbé váltak a témában. Tehát a képzések nemcsak abban voltak hatásosak, hogy általában fejleszszék a diákok pénzügyi ismereteit, de a nemek közti eltérések csökkentésében is nagy szerepük lehet (Amagir et al., 2017), és nem kizárólag a diákok, hanem akár a felnőtt lakosság körében is (Hasler, Lusardi, 2017).
A fiatalok pénzügyi kultúrájának fejlesztése kiemelt területe a Nemzeti Pénzügyi Tudatosság stratégiának és kapcsolódó cselekvési tervnek. A stratégia első célkitűzése kifejezetten a köznevelésen belüli pénzügyikultúra-fejlesztésre vonatkozik, de emellett megfogalmaz célokat a pénzügyi stressztürő képesség és a felnőtt lakosság pénzügyi tudatosságának fejlesztésére is (Kovács, Sütő, 2020). A stratégia magában foglalja többek között a pénzügyi tudatosság Nemzeti Alaptantervbe történő beépítését, amelynek eredményeként elkészült az általános iskolásoknak szánt Küldetések a pénz világában és a középiskolásoknak szánt Iránytü a pénzügyekbe címü tankönyv is (Kovács, 2018).

Számos szervezet közreműködik a fiatalokat, illetve pedagógusokat célzó fejlesztő programok megvalósításában. Németh és szerzőtársai (2020a) 2016-ban és 2020-ban is felmérték, hogyan alakultak a különböző kormányzati és nem kormányzati pénzügyikultúra-fejlesztési programok. Eredményeik azt mutatják, hogy van igény a pénzügyi kultúra fejlesztésére és ennek a különböző szervezetek igyekeznek eleget tenni. 2016-hoz képest közel megháromszorozódott a képzésekkel és programokkal elértek száma, és ez a növekedés a fiatalok esetén még nagyobb mértékű volt. A 2020-as vizsgálat szerint az elmúlt négy évben több mint 1,1 millió fiatalt sikerült elérni a programokkal. A szerzők által közzétett részletes elemzés kitér arra, hogy a fiatalok jelentősen túlreprezentáltak ezeken a képzéseken, tehát folyamatos a diákok pénzügyi kultúrájának fejlesztése, ahogy az az előzőekből látszik, mind az iskolarendszeren belül, mind azon kívül, tematikus foglalkozásokon és rendezvényeken keresztül.

A PÉNZ7-rendezvénysorozat - amely 2015 óta minden évben megrendezésre kerül - programjain keresztül minden évben több százezer diákhoz juttatja el tematikus előadásokon keresztül a legfrissebb pénzügyi és vál- 
lalkozói ismereteket (Kovács, 2018; Kovács, Terták, 2019; Kovács, Sütő, 2020).

Összességében a képzések kulcsfontosságúak ebben a korban, hiszen az általános és középiskolások fiatal koruknál fogva jóval nyitottabbak az új ismeretek iránt, emellett gyorsabban és könnyebben is tanulnak, mint a felnőttek. Természetesen nem elhanyagolható a felnőttek képzése sem, azonban minél fiatalabb korban kezdjük a diákokat pénzügyeikben tudatosságra nevelni, annál felelősebbek lesznek felnőtt korukra.

\section{AZ ECONVENTIO-TESZT}

Az Econventio és partnerszervezetei fő célja a középiskolások pénzügyi, gazdasági ismereteinek kutatásokra épülő fejlesztése, azaz éves felmérések segítségével azonosítani a problémás ismeretterületeket, megvizsgálni a problémák okát, majd erre fejlesztési tevékenységeket kidolgozni. Jelen fejezetben először bemutatjuk a vizsgálati modell elméleti hátterét, majd a felmérés, az Econventio-teszt módszertani jellemzőit.

A cselekvő közgazdaságtani racionalitása mentén meghatározott három aspektust - információgyűjtés (ismeretek, csatornák, tapasztalatok), preferenciák (attitűdök, értékrend, személyes pénzügyi helyzet, jövőbeli tervek), döntéshozatal (alternatívák közötti választás) - vizsgálunk behatóbb módon, hat vertikális dimenzión keresztül. Hogarth, Hilgert, Beverly (2003) ajánlását figyelembe véve a következő vertikális dimenziókhoz kapcsolódó témaköröket vontuk be a vizsgálatba:

(1)általános banki, pénzügyi ismeretek (számlavezetés, tranzakciós költségek, bankkártyahasználat, bankrendszer, szolgáltatások),

2 befektetések, megtakarítások (befektetési formák, célok, időtávok, kamat és hozam különbsége, hozam és kockázat kapcsolata),
3 hitelek (diákhitel, egyéb hitelfajták és jellemzőik),

4 munka világa (diákmunka, oktatás, adózás, vállalkozás),

5 biztosítás, nyugdíj (öngondoskodás, nyugdíjrendszer, biztosítások típusainak jellemzői),

6általános gazdasági ismeretek (infláció, államadósság, adózás).

$\mathrm{Az}$ Econventio-teszt, illetve ennek kérdései alapvetően két részből állnak: 10 darab attitűdvizsgálati kérdésből, illetve 30 kérdést tartalmazó tudástesztből. A teszt során mind a hat vizsgálati dimenzió egyforma súllyal alakítja a modellt. Ez azt jelenti, hogy minden egyes vizsgálati dimenzióban öt tudástesztkérdés, négy ismereteket és informáltságot ellenőrző kérdés jelenik meg, illetve egy a számolásokhoz, ajánlatokhoz köthető. Emellett minden témakörben legalább egy attitűdhöz köthető kérdés is megjelenik, ahol nincs helyes válasz. A tudásteszteknél, amely tartalmazza a pénzügyi ismeretek és a számolási készségek vizsgálatát is, elsősorban nem fogalmak definiálásán van a hangsúly, hanem gyakorlatcentrikus kérdéseken. Kérdésenként négy válaszalternatíva áll rendelkezésre, amelyből egy helyes. Ettől az elvtől akkor történik eltérés, ha egy kérdés nemzetközi mérőeszközből kerül kiválasztásra, a nemzetközi összehasonlíthatóság érdekében, vagy ha olyan kérdésről van szó, amelyben a kitöltőnek két ajánlat közül kell választania. Mivel számos esetben (például hitelkártya, tőzsde) a diákok nem rendelkeznek megfelelő tapasztalattal, felmerül a kérdés, hogy valóban a középiskolások tudását tükrözik-e a válaszok, nem pedig csak véletlenszerű tippeléseket. E torzító tényező hatásának csökkentése miatt a tudásteszt kérdéseinél egy „Nem tudom” válaszalternatíva is rendelkezésre áll, arra kérve a diákokat, hogy ezt az alternatívát válasszák, amennyiben elképzelésük sincs a helyes válaszról.

A kitöltőknek összesen 40 kérdést kell megválaszolniuk, ami nem tartalmazza az általá- 
nos demográfiai kérdéseket, ugyanis azokat a regisztráció folyamán kell megadniuk. Az Econventio-teszt kitöltésére előzetes regisztráció után az Econventio Egyesület honlapján (www.econventio.hu) nyílik lehetőség, minden év tavaszán. Regisztráció során meg kell adni a kitöltő osztálytípusát, iskolatípusát, képzési programját (gazdasági, nem gazdasági), nemét, életkorát és évfolyamát. Az adatfeldolgozás már anonim adatokat tartalmaz. Kitöltés közben a felületen a kitöltőnek egyszerre csak egy kérdés jelenik meg, a kérdések megválaszolására összesen 30 perc áll rendelkezésre. A kitöltésben az Econventio-iskolahálózat 200 iskolájának diákjai vettek részt, akik órai keretek között töltötték ki az online tesztet.

A tesztkérdések ugyan az évek során változnak, azonban a fömodellen belül azonos témacsoportra kérdezünk rá. Mivel egy-egy dimenzió komplex módon nem vizsgálható csupán öt-öt tudásteszttel, ezért fejlesztési pontokat, irányvonalakat azzal lehet kijelölni, ha az elmúlt évek eredményeit összekapcsoljuk, így ugyanis minden dimenzióra már komplexebb kép adódik, ami mélyebben vizsgálható, elemezhetö.

\section{MÓDSZERTAN}

Az Econventio-teszt 2011-ben indult, 10 évre visszamenő adatbázissal rendelkezünk a középiskolások pénzügyi kultúrájára vonatkozóan. A tesztet évente átlagosan több mint tízezer középiskolás töltötte ki, amelynek eredményeképp összes 104758 darab kitöltött teszt gyült össze. Mivel maguknak a kérdéseknek és válaszalternatíváknak az elolvasása 4-4,5 percet vesz igénybe, így jelen elemzéseink során kiszürtük az 5 percnél alacsonyabb kitöltési idővel rendelkező egyedeket, amelyek nagy valószínűséggel csak véletlenszerűen, vakon kitöltött teszteket tartalmaznak.

Az elmúlt évek során a diákok teszten elért átlagos teljesítménye minden évben 40-55 százalék között mozgott, ami azt jelenti, hogy a 30 tudástesztből átlagosan 12-16 kérdést tudtak helyesen megválaszolni. Az elemzéseinket két dimenzióban végeztük és az eredményeinket is két nagyobb csoportra bontottuk. Egyrészt éves szinten vizsgáltuk a különböző attitűdkérdések és a teszten elért teljesítmény között fennálló kapcsolatokat, másrészt vizsgálatokat végeztünk olyan demográfiai tényezők mentén, amelyek az évente változó attitűd- és tudáskérdésekkel ellentétben minden évben, állandó jelleggel előfordultak a tesztben. Ezek a demográfiai tényezők a nemekre, a korcsoportra, az iskola és a képzési formára vonatkozó kérdések.

$\mathrm{Az}$ elemzésekhez egy- és többszempontos varianciaanalíziseket (ANOVA) alkalmaztunk.

$\mathrm{Az}$ egyszempontos modell lineáris formában felírható:

$y_{i j}=\bar{y} .+a_{j}+e_{i j}$

Ahol

$y_{i j}$ a tudásteszten elért teljesítmény, a helyes válaszok száma,

$\bar{y}$. a fóátlag, az átlagos teljesítmény,

$a_{j}$ a kategoriális változó hatás,

$e_{i j}$ a hibatag.

Többszempontos modellben a kategoriális változók fö hatásai mellett a közöttük fennálló interakciós-hatások is megjelennek. Két kategoriális változó esetében (Denis, 2016):

$y_{i j k}=\bar{y}_{. .}+a_{j}+b_{k}+(a b)_{j k}+e_{i j k}$

Ahol

$y_{i j k}$ a tudásteszten elért teljesítmény, $a$ helyes válaszok száma,

$\bar{y}$. a fóátlag, az átlagos teljesítmény,

$a_{j}$ az egyik kategoriális változó hatás,

$b_{k}$ a másik kategoriális változó hatás,

$(a b)_{j k}$ a kategorikus változók interakciós hatása,

$e_{i j k}$ a hibatag. 
Kettőnél több kategorikus változót tartalmazó varianciaanalízis esetén az interakciós hatásokat a többi fö hatás és az interakcióban szereplő egyéb hatások duplikációinak kiszürésével kaphatjuk meg. Jelen tanulmányban legfeljebb három kategorikus változó jelenik meg.

Az F-próbák esetében 5 százalékos szignifikanciaszint mellett döntöttünk a hipotézisek elvetéséről, a csoportátlagok eltéréseit pedig Post Hoc-tesztek segítségével is vizsgáltuk, ami a csoportátlagok különbségeit páronként hasonlítja össze az összehasonlítások számával korrigált $t$-próbák segítségével. Az eredmények interpretálása során minden esetben feltüntettük a kapcsolatmérő $(H)$ mutató értékét, illetve feltüntetjük a tesztek során nyert p-értékeket. A kérdőívek eredményeinek vizsgálatához minden esetben Excel-kimutatásokat, illetve IBM SPSS statisztikai szoftvert használtunk.

\section{EREDMÉNYEK}

A nagyszámú kitöltéseknek köszönhetően minden évben számtalan megállapítást tehettünk az Econventio-teszt alapján a hazai középiskolásokra, amelyek magyarázatul szolgálhatnak a pénzügyi tudásukban tapasztalható különbségekre. Jelen tanulmányban igyekeztünk ezek közül a legfontosabb összefüggéseket, általánosan levonható következtetéseket kiemelni.

\section{Az informáltság szerepe}

A tesztek során több kérdés mentén tettünk kísérletet a középiskolások informáltsága és pénzügyi tudása közötti kapcsolat feltérképezésére. Nemzetközi kutatások szerint (lásd OECD, 2020b) a szülőktől szerzett információk, az úgynevezett családi mintázat jelentős mértékben rányomhatja a bélyegét a középiskolások pénzügyi tudására. Erre utaló bizonyítékokat minden, a kérdést vizsgáló évben találtunk. A diákok elsődleges pénzügyi információforrásként négy fö forrást jelöltek meg. Az otthonlátottak (45,6 százalék), az iskolában tanultak (20,9 százalék), az interneten található információforrások (10,3 százalék), valamint a saját tapasztalat (12,3 százalék). Az otthonlátottak vezető szerepe mellett az OECD (2020b) vizsgálataival összhangban megállapítható az internetes források használatának fokozatos térnyerése 2015 óta. Az internetes források elsődleges szerepét már közel ugyanakkora arányban jelölik meg a válaszadók, mint az iskolában szerzett információkat. A fó információforrások függvényében jelentős különbségek tapasztalhatók a diákok átlagos teljesítményei között. Ahogyan az 1. ábrán is látható, az elsősorban internetes forrásokra támaszkodó kitöltők általánosságban szignifikánsan több kérdésre tudtak helyesen válaszolni. Öket követték azok, akik számára az iskola jelenti az elsődleges információforrást, majd a saját tapasztalatra támaszkodók és végül, a legalacsonyabb átlagos teljesítménnyel azok rendelkeztek, akik a családot jelölték meg pénzügyi ismereteik fó forrásaként.

\section{Az értékrend és a pénzügyi tudás közötti kapcsolat}

A pénzügyekhez való hozzállláshoz kapcsolódó kérdések segítségével szignifikáns kapcsolatot tudtunk kimutatni a tudásteszten elért teljesítmény és az attitűd között, miszerint a nagyobb érdektelenség szignifikánsan gyengébb teljesítményt indukálhat. Ezt az adócsalással és korrupcióval kapcsolatos kérdésekkel lehet a leginkább szemléltetni. A 2013-as teszt eredményei alapján a középiskolások többsége (72,6 százalék) szerint egyáltalán nem elfogadható az adócsalás. Azok közül, akik ezt nem így 


\section{A HELYES VÁLASZOK ÁTLAGOS SZÁMA A ,,LEGFŐKÉPPEN HONNAN MERÍTED PÉNZÜGYI ISMERETEID?" KÉRDÉSRE ADOTT VÁLASZOK ALAPJÁN (2012, N = 8007, H = 0,204, P-ÉRTÉK<0,001)}

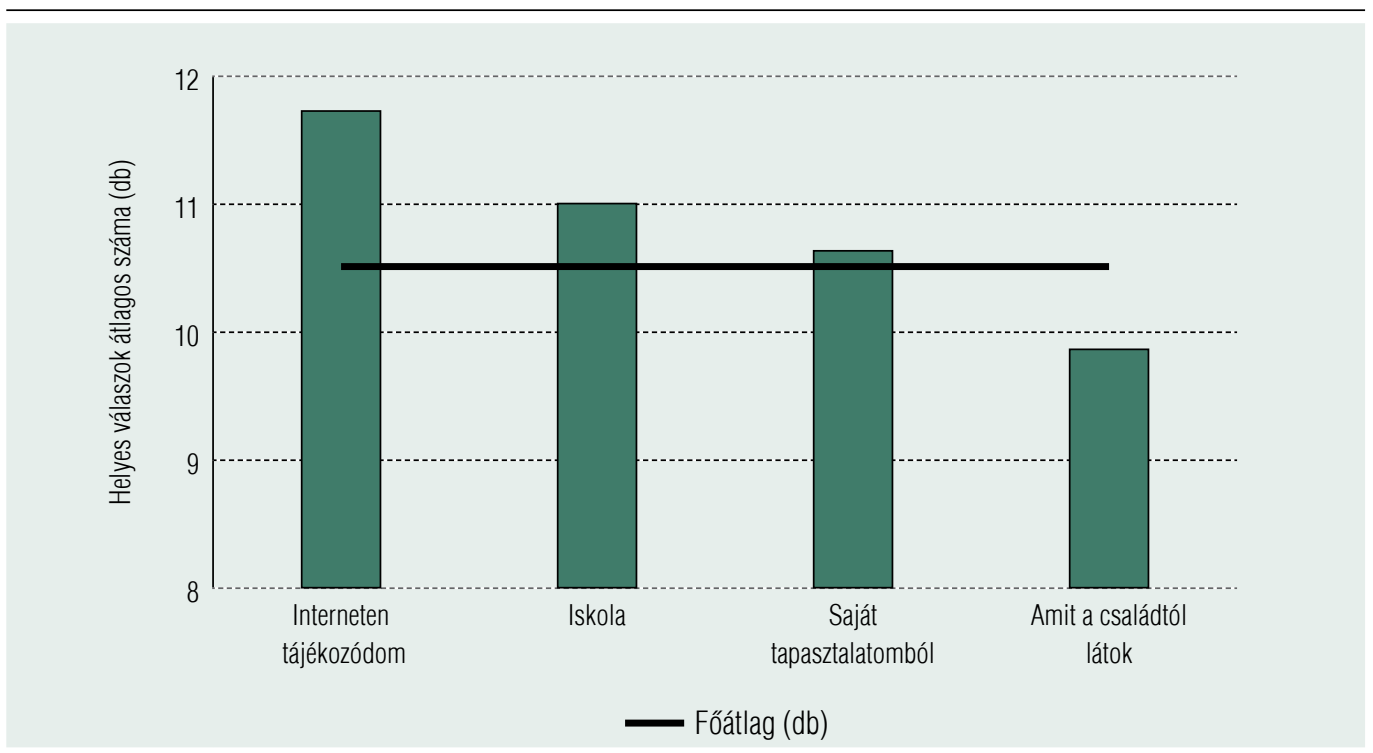

Forrás: saját szerkesztés

gondolják 42,9 százalék szerint akkor elfogadható, ha túl magasak az adók, míg 38,8 százalék szerint akkor, ha nem értenek egyet azzal, hogy az állam mire költi az adófizetők pénzét, illetve 18,3 százalék szerint akkor megengedhető az adócsalás, ha mindenki más is ezt csinálja. Az eredmények alapján azonban szignifikánsan jobb eredményt értek el azok, akik egyértelműen elutasítják ezt a fajta tevékenységet (2. ábra).

Hasonló eredményekre jutottunk a 2017 es és a 2019-es tesztek során, amelyekben a diákok korrupcióhoz való hozzálllására kérdeztünk rá. 2017-ben a válaszadók közül 44,1 százalék egyértelműen elhatárolódott az efféle cselekedettől, 38,3 százalék azonban nem ítélte el, 17,6 százalék pedig azt nyilatkozta, hogy nem foglalkozik vele. Mind a két évben egyaránt igaz volt, hogy a tudásteszten szignifikánsan jobb átlagos teljesítményt nyújtottak azok, akik határozottan elzárkóznak ettől a fajta cselekedettől (3. ábra). A kérdés tekintetében azonban negatív változások voltak tapasztalhatók az utolsó két év viszonyában. 2019-ben már csak 36,0 százalék nyilatkozott úgy, hogy a korrupció nem fér bele az erkölcsi normáiba. A 2017-es évhez hasonlóan a válaszadók közel harmada nem ítélte el a korrupció intézményét, azonban emelkedett azoknak az aránya, akiket nem foglalkoztat ezt kérdés.

\section{A pénzügyi tervezés jelentősége}

A tesztek során rendszeresen tapasztaljuk, hogy azok a diákok, akik előre terveznek, fontosnak tartják a pénzügyi tervezés folyamatát általában jobban teljesítenek a tudásteszteken. A diákok 77,0 százaléka ugyan fontosnak tartja a családban bevételek és kiadások nyilvántartását, de közülük csak 53,3 százalék képes saját 


\section{A HELYES VÁLASZOK ÁTLAGOS SZÁMA A „SZERINTED MILYEN ESETBEN ELFOGADHATÓ ADÓT CSALNI?’ KÉRDÉSRE ADOTT VÁLASZOK ALAPJÁN (2013, $\mathrm{N}=10627, \mathrm{H}=$ 0,248, P-ÉRTÉK<0,001)}

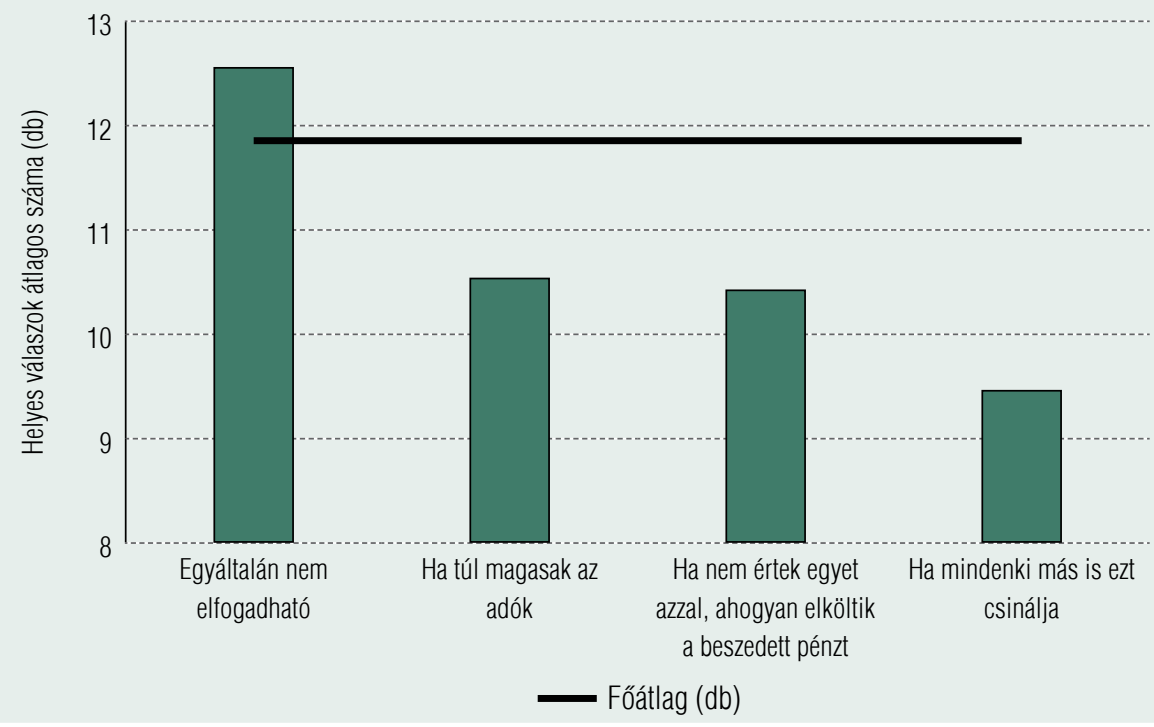

Forrás: saját szerkesztés

\section{A HELYES VÁLASZOK ÁTLAGOS SZÁMA A „MIT GONDOLSZ A KORRUPCIÓRÓL?” KÉRDÉSRE ADOTT VÁLASZOK ALAPJÁN}

$(2017, \mathrm{~N}=10929, \mathrm{H}=0,322)$

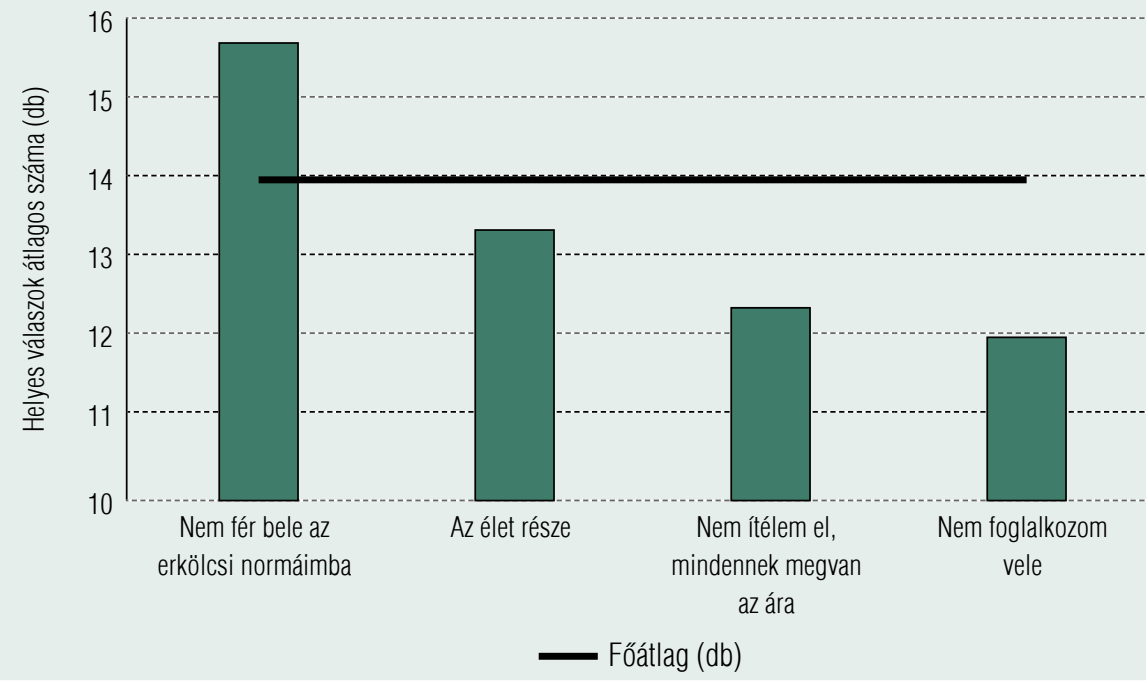

Forrás: saját szerkesztés 
maga is elkészíteni egy ilyen pénzügyi mérleget. A válaszadók 23,0 százaléka szerint nem fontos, sőt ezen belül a diákok nagy része szerint (65,7 százalék) otthon nem is készítenek ilyet. Az eredmények alapján, ahogyan az a 4. ábrán is jól látható a teszten jelentősen jobb átlagteljesítménnyel rendelkeztek azok, akik szerint fontos, sőt el is tudnának készíteni egy ilyen mérleget.

A pénzügyi tervezés kapcsán 2018-ban és 2020-ban a középiskolások nyugdíjas évekre történő megtakarítással kapcsolatos véleményére voltunk kíváncsiak. 2018-ban a diákok alacsony hányada (9 százalék) gondolta úgy, hogy nem szükséges a nyugdíjas évekre megtakarítani. A többségük tehát elismeri az időskorra történő megtakarítások fontosságát, ugyanakkor abban már megoszlik a véleményük, hogy ezt mikor érdemes elkezdeni. 43,7 százalék szerint már az első rendszeres fizetéstől kezdve el kell kezdeni takarékoskodni a nyugdíjas évekre. 37,6 százalék szerint ez elegendő a nyugdíj előtt 20-30 évvel, 11,5 százalék szerint csupán 10 évvel, míg 7,2 százalék szerint erre egyáltalán nincs is szükség. A 2020as teszt eredményei alapján ezek az arányok nem változtak jelentős mértékben. Érdemes azonban megfigyelni, hogy a nyugdíjas évekre történő megtakarítási hajlandóság és a tudásteszten elért eredmények között is kapcsolat rajzolódik ki. A 2020-as évre vonatkozó kérdés Post Hoc teszt eredményei alapján a helyes válaszok átlagos számának tekintetében jelentős mértékben kiemelkedtek azok, akik szerint már az első rendszeres fizetéstől kezdve érdemes megtakarítani. Ezzel ellentétben jelentősen alacsonyabb átlagos teljesítményt nyújtottak azok, akik szerint ez elegendő 10 évvel a nyugdíj előtt, vagy egyáltalán nincs is rá szükség (5. ábra).

\section{A HELYES VÁLASZOK ÁTLAGOS SZÁMA A „MIT GONDOLSZ A CSALÁDI PÉNZÜGYI MÉRLEGRÖL?" KÉRDÉSRE ADOTT VÁLASZOK ALAPJÁN $(2014, \mathrm{~N}=9400, \mathrm{H}=$ 0,322, P-ÉRTÉK<0,001)}

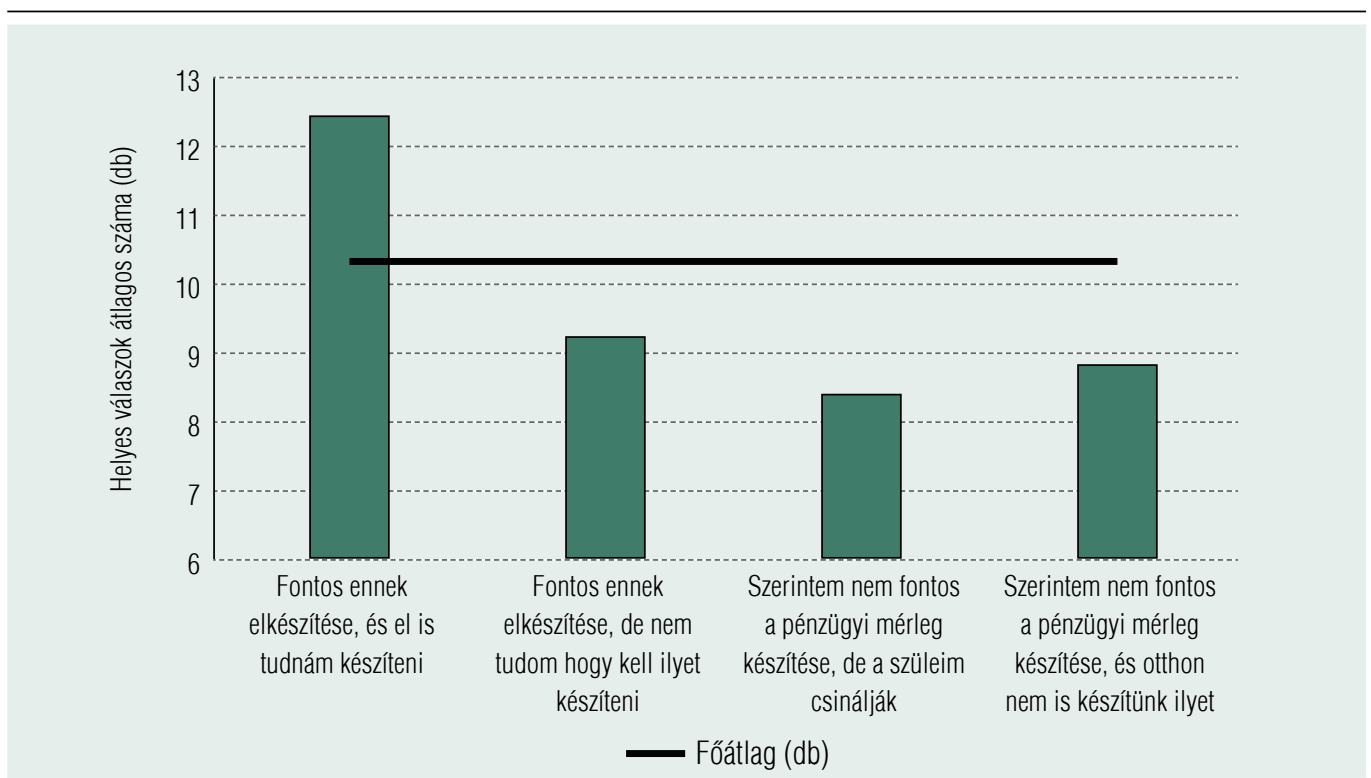

Forrás: saját szerkesztés 


\section{A HELYES VÁLASZOK ÁTLAGOS SZÁMA A ,SZERINTED MIKOR ÉRDEMES ELKEZDENI TAKARÉKOSKODNI A NYUGDÍJAS ÉVEKRE?" KÉRDÉSRE ADOTT VÁLASZOK ALAPJÁN (2020, $\mathrm{N}=5$ 5047, $\mathrm{H}=$ 0,235, P-ÉRTÉK<0,001)}

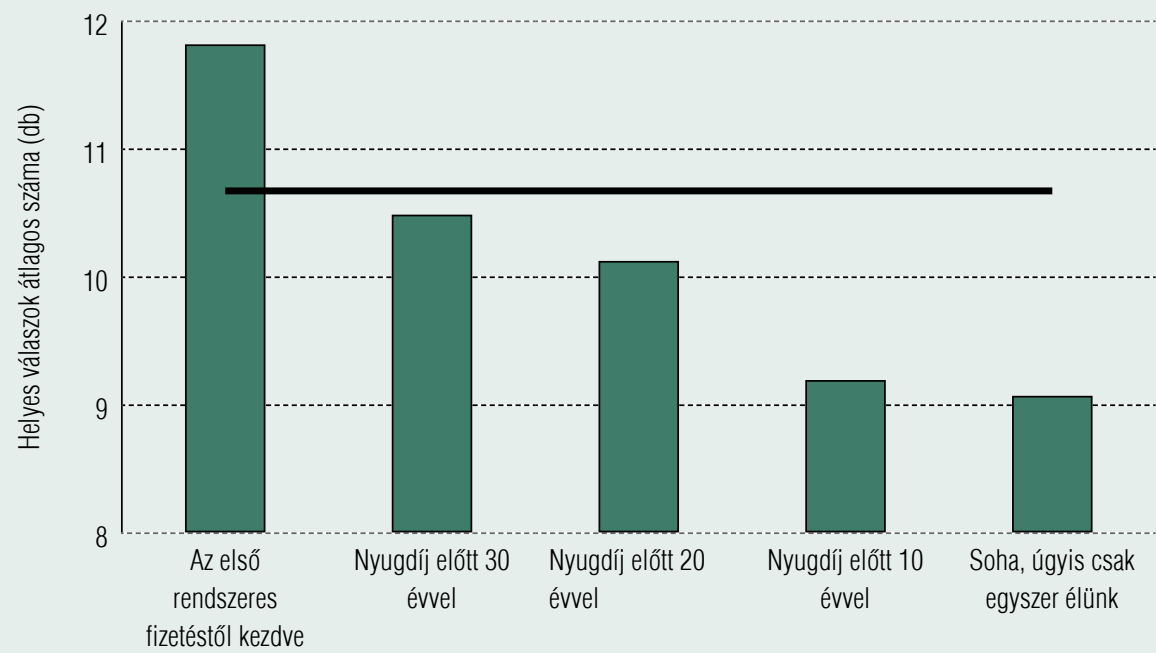

Főátlag (db)

Forrás: saját szerkesztés

\section{Demográfiai tényezők mentén tapasztalható egyenlőtlenségek}

A pénzügyi tudást az informáltságon és pénzügyekhez való hozzáálláson túl egyéb, demográfiai tényezők is jelentős mértékben befolyásolhatják. Egyrészt, a nemzetközi vizsgálatokkal összhangban nagyságrendileg hasonló különbség mutatható ki a férfiak és a nők teszten elért átlagos eredményei között ( $p$-érték $<0,001)$. Az egyes tudástesztek éves átlagához viszonyítva az elmúlt kilenc évben a férfiak átlagosan 6,72 százalékponttal jobban teljesítettek, mint a nők. Ugyanakkor, arra érdemes felhívni a figyelmet, hogy ezeknek a különbségeknek az értelmezésekor fontos a tesztkérdések számát is vizsgálni. Az Econventio-teszt esetében, ahol 30 tudást mérő tesztkérdés található, a 6,72 százalékpontnyi különbség azt jelenti, hogy a férfiak 30-ból átlagosan kettővel több kérdést válaszolnak meg helyesen, mint a nők. Általánosan, ha egy mérőeszköz $k$ darab kérdést tartalmaz, akkor 1 kérdés súlya a helyes válaszok arányában 100/k. Ugyancsak szignifikáns kapcsolat figyelhető meg az életkor és a teszten elért teljesítmények vonatkozásában $(\bar{H}=0,256$, $p$-érték $<0,001)$. Az idősebb diákok általában több kérdésre tudtak helyesen válaszolni, mint fiatalabb társaik. A vizsgált időszakban a 14-15 éves korosztályhoz képest a 18 évnél idősebb korosztály átlagosan 28,13 százalékponttal teljesített jobban, ami a gyakorlati tapasztalatok növekedésével is magyarázható. Mindezek mellett jelentős különbség volt megfigyelhető a középszintü oktatási intézmények típusa $(\bar{H}=0,160, p$-érték $<0,001)$, illetve a gazdasági képzésen és nem gazdasági képzésen tanuló diákok teszten elért teljesítménye között $(\bar{H}=0,114, p$-érték $<0,001)$. A gimnáziumban tanulók az adott évek át- 
lagos pontszámaihoz viszonyítva átlagosan 15,48 százalékponttal nagyobb arányban válaszoltak helyesen, mint a szakközépiskolában (2016 előtt szakmunkásképzőben) tanuló diákok. A gazdasági képzésben részesülő középiskolások pedig átlagosan 11,94 százalékponttal múlták felül a nem gazdasági képzésben részt vevő társaikat. A kapcsolatmérő mutatók a kapcsolat szignifikáns volta mellett alacsony, illetve közepes erősségű kapcsolatot jeleznek a teszten elért teljesítmény és a demográfiai tényezők között, ami arra utal, hogy ezeknek a tényezőknek a kapcsolata egyenként releváns, de célszerű lehet ezek együttese és a kereszthatások figyelembevétele mellett vizsgálni a teljesítménykülönbségeket.

\section{Az egyenlőtlenségek gazdasági képzésekkel jelentős mértékben mérsékelhetők}

A korábban említett, demográfiai tényezőkhöz kapcsolódó jelenségek között jelentős kereszthatások is megfigyelhetők. Ezek kimutatására többszempontos varianciaanalíziseket alkalmaztunk, amelyekben a nemeket, az életkort és a képzési típust együttesen szerepeltettük. Ezeket az elemzéseket minden évre elvégeztük, illetve összességében a kilenc évre vonatkozóan is lefuttattuk. Az iskolával, osztálytípussal kapcsolatos kérdéseket a vizsgált időszak felénél, a 2016/2017-es tanévben bekövetkező, szakképző intézményekre vonatkozó név és feladatellátáshoz kapcsolódó változások miatt nem találtuk célszerűnek ezekben az elemzésekben szerepeltetni. A többszempontos varianciaanalízis eredményei rávilágítanak arra, hogy a pénzügyi tudásban tapasztalható egyenlőtlenségek jelentős mértékben csökkenthetők pénzügyi, gazdasági képzések segítségével.

A fó hatások (nemek, képzés, korcsoport) és a kétszeres kereszthatások szignifikánsnak bizonyultak, ugyanakkor a három ténye- ző együttes interakciója nem volt szignifikáns. Megállapítható, hogy a gazdasági képzésen részt vevő diákok tudása jelentősen gyorsabb ütemben fejlődik, mint a nem gazdasági képzésen tanuló középiskolásoké. A 6. ábrán is jól látható, hogy amíg a fiatalabb, 14 és 15 éves korosztály esetében nem volt jelentős különbség a két képzési típuson tanuló diákok átlagos teljesítménye között, addig a 16. életévtől ez a különbség szignifikánssá vált és az életkor előrehaladtával folyamatosan növekedett. A 19 éves korosztályban az átlaghoz viszonyított átlagos különbség 16,56 százalékpont volt a két típusú képzés között. Ennek az oka az, hogy a gazdasági képzésekben a képzés elején csak egy alapozó gazdasági tantárgy található, míg a szakmai törzsanyag jellemzően a 11. évfolyamtól jelenik meg, ezzel párhuzamosan nő a két csoport közötti teljesítménykülönbség a gazdasági képzésekben tanulók javára.

Megfigyelhető, hogy a nemek közötti teljesítménykülönbség a gazdasági képzésen részt vevő diákok esetében jelentősen alacsonyabb volt. Ezt természetesen nagy mértékben befolyásolta az is, hogy a különböző években milyen jellegű kérdéseket tettünk fel a középiskolásoknak, de 5 százalékos szignifikanciaszinten a kilenc évből öt esetben jelentkezett ez a hatás. A 7. ábrán is jól látható, hogy az elmúlt időszak eredményei alapján: míg a nem gazdasági képzésen résztvevők esetében jelentős, átlagosan 8,72 százalékpontos különbség volt a férfiak és a nők átlagos teljesítménye között, addig ez az arány 5,15 százalékponttal alacsonyabb volt a gazdasági képzésen tanuló diákok között.

Mindezek mellett az is megállapítható, hogy az életkor elörehaladtával ugyan jelentős mértékben növekszik a pénzügyi ismeretek szintje, a nemek közötti egyenlőtlenség is némiképp mérséklődik. Erre utal a nemek és a korcsoport között több évben is felfedezhető szignifikáns kereszthatás. Ahogyan az a 8 . ábrán is látható, a 15 évesek körében 7,9 százalékpontnyi különbség fedezhető fel a férfiak és 


\section{A HELYES VÁLASZOK ÁTLAGOS SZÁMA A KÉPZÉSI TÍPUS ÉS AZ ÉLETKOR FÜGGVÉNYÉBEN}

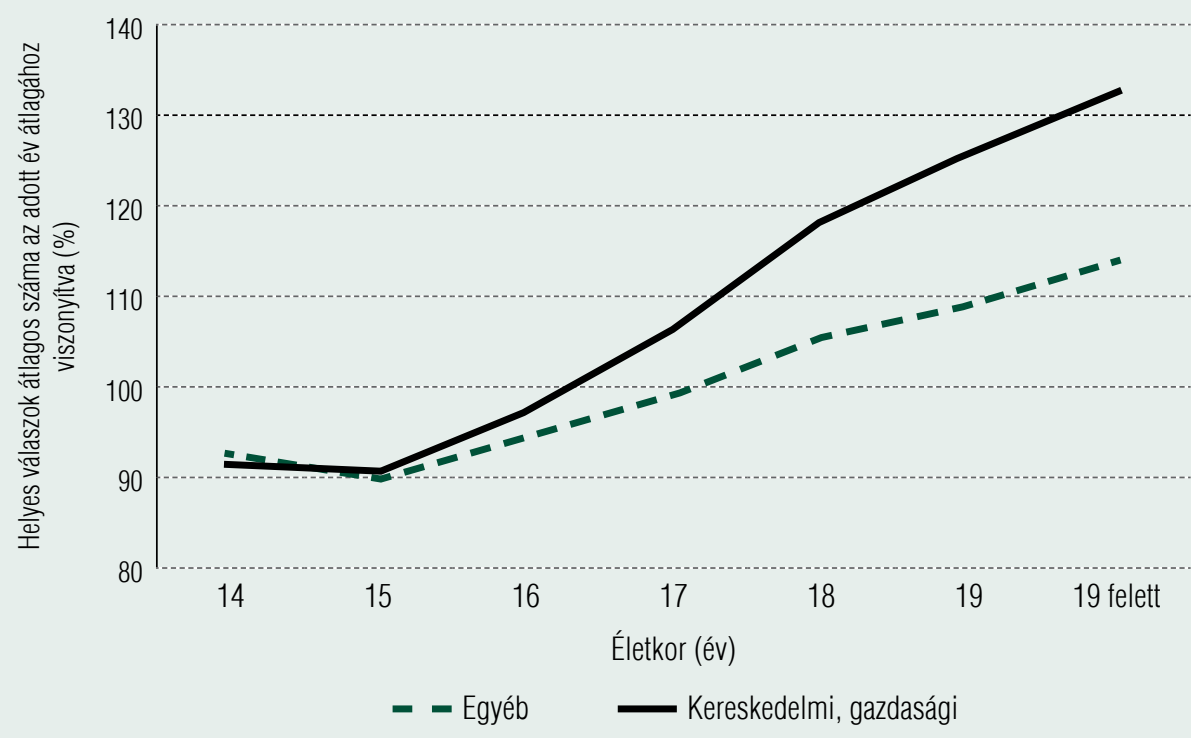

Forrás: saját szerkesztés

7. ábra

\section{A HELYES VÁLASZOK ÁTLAGOS SZÁMA NEMEK ÉS KÉPZÉSI TÍPUS} FÜGGVÉNYÉBEN

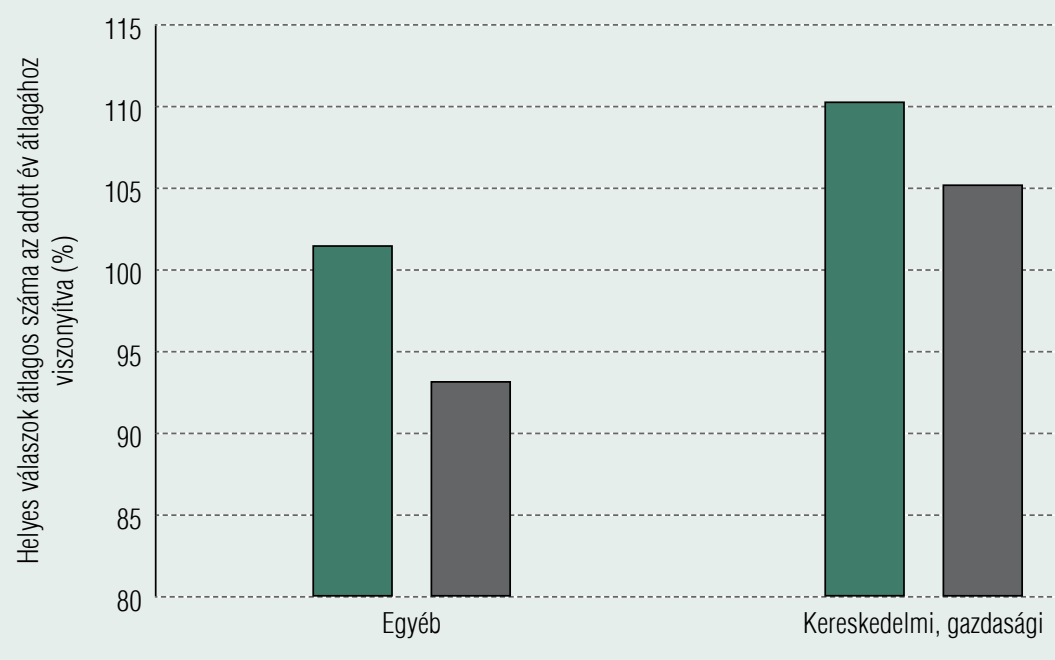

Férfi Nő

Forrás: saját szerkesztés 


\section{A HELYES VÁLASZOK ÁTLAGOS SZÁMA NEMEK ÉS KÉPZÉSI TÍPUS FÜGGVÉNYÉBEN}

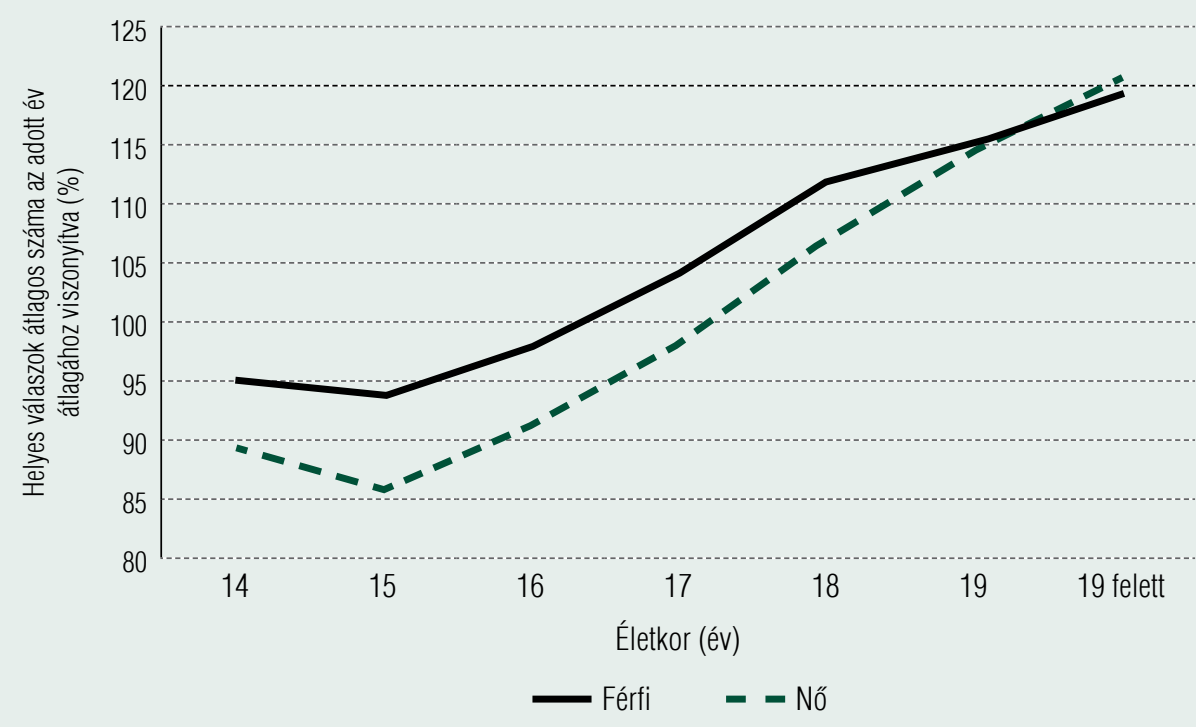

Forrás: saját szerkesztés

a nők átlaghoz viszonyított átlagos teljesítményei között, addig a 19 évesek körében ez a differencia szinte teljesen eltűnik.

Ez a közeledés egyrészt a pénzügyi tapasztalatokkal magyarázható, hiszen idősebb korban, kiváltképp a 18. életévet betöltve nemtől függetlenül minden középiskolásnak szembe kell néznie az felnőttkort érintő általános pénzügyekkel. Azonban ez a közeledés is a gazdasági képzésen részt vevő középiskolások esetében általában, valamivel erőteljesebb. Míg a nem gazdasági képzésen tanuló 15 évesek körében 8,15 százalékpont a nemek közötti differencia, ami a 19. életévre 6,1 százalékpontra csökken, addig a gazdasági képzésen tanulók esetében ez a két érték 3,1 és 0,2 százalékpont. E ponton érdemes megjegyezni, hogy az Econventiotesztet kísérleti jelleggel 4 alkalommal felnőtt kontrollcsoporttal is kitöltettük 1500-2000 fös mintákon. Az nem meglepő eredmény, hogy a gyakorlati tapasztalatoknak köszönhe- tően, minden kérdés esetében a felnőttek átlagteljesítménye jobb, mint a középiskolásoké, ugyanakkor a helyes válaszok arányainak sorrendjét vizsgálva minden alkalommal 0,8-nél magasabb rangkorrelációs együttható értéket kaptunk, ami arra utal, hogy a helyes válaszok arányát tekintve a kérdések sorrendje ugyanaz mind a diákok, mind a felnőttek esetében. Azaz, ami fiatal korban problémát jelent, az a felnőtteknél is. Megfordítva, ha egy-egy pénzügyi, gazdasági ismeretkör gyakorlatias oktatását beépítjük a köznevelésbe, akkor várhatóan a későbbiekben ezen területek kevésbé fognak problémát jelenteni a felnőttkorban.

\section{ÖSSZEFOGLALÁS}

Tanulmányunk célja az volt, hogy összefoglaljuk az Econventio-teszt elmúlt 10 évének főbb eredményeit is megállapításait. Az ered- 
ményeink azt mutatják, a fiatalok nem feltétlen vannak tisztában az őket körülvevő világ folyamataival, és a nemzetközi eredményekhez hasonlóan a magyar középiskolások (közülük is kifejezetten a szakiskolai és szakközépiskolai oktatásban résztvevők) pénzügyi tudása rendkívül alacsony, minden évben elmaradt a felnőtt lakosság pénzügyi tudásától. A digitális pénzügyi szolgáltatásokkal kapcsolatos attitűdjeik és magatartásuk összhangban áll az irodalomban leírtakkal.

A pénzügyi tudás kapcsolatban áll az öngondoskodásról alkotott véleménnyel. Azok pénzügyi tudásszintje magasabb, akik hosszabb távon gondolkodnak, akik korábban kezdenek nyugdíjas éveikre megtakarítani. A nemzetközi vizsgálatokhoz hasonló eredményre jutottunk abban, hogy a középiskolások pénzügyek iránt tanúsított hozzáállása szignifikáns kapcsolatban áll a pénzügyi tudásszintjükkel, ezzel is igazolva, hogy nemcsak tudást, de attitűdöt is fejleszteni kell. Azok, akiket nem érdekelnek a pénzügyi hírek, alacsonyabb pénzügyi tudással rendelkeznek, ami szintén alátámasztja azt, hogy nemcsak pénzügyi ismeretek átadására van szükség, hanem azok fontosságának hangsúlyozása, az érdeklődés felkeltése is kiemelt jelentőségű lehet.

Az elmúlt 10 év eredményei szerint a középiskolások pénzügyi ismereteiket legföképpen az otthonlátottakból merítik. Ezután következik az iskola és az internet. Gazdasági képzések esetén, felsőbb évfolyamokon nő azok aránya, akik az iskolában szerzett tudásukat próbálják meg pénzügyeik során felhasználni. Ugyanakkor, évfolyamtól függetlenül a nem gazdasági képzésekre járók csupán 10 százaléka próbálja az iskolában tanultakat pénzügyei során alkalmazni. Az otthoni hibás mintázat követése megmutatkozik a teszteredményekben: a pénzügyi tudásteszten azok teljesítenek jobban, akik az iskolában tanultakra próbálnak hagyatkozni. Mind a gazdasági, mind a nem gazdasági képzésben tanulók tu- dásszintjét vizsgálva elmondható, hogy a hétköznapi, gyakorlati kérdések tekintetében nincs jelentős különbség a két csoport között, ugyanakkor minél magasabb évfolyamot vizsgálunk, a két csoport elméleti tudásszintje között nyílik az olló. Középfokú oktatási szinten megállapítható, hogy a szakiskolák tanulóinak pénzügyi tudásszintje leszakad a szakgimnáziumok és gimnáziumok tanulóinak tudásszintjétől. A szakiskolákban végzettek közül sokan szakmunkás vállalkozóként lakossági szolgáltatásokat fognak nyújtani, amelyhez kötődően ki kell tudniuk állítani egy számlát, azaz pénzügyi és vállalkozói ismeretekkel is kell, hogy rendelkezzenek. E szempontból különösen fontos a szakiskolákban tanulók leszakadásának csökkentése.

Az életkor előre haladtával, a gyakorlati tapasztalatok gyarapodásával a pénzügyi tudásszint nő. Ugyanazokat a pénzügyi kérdéseket a felnőttek nagyobb arányban válaszolják meg helyesen, mint a középiskolások, ugyanakkor a felnőttek és középiskolások esetében is ugyanazok a kérdések, ismeretkörök jelentenek nagyobb nehézséget. Emellett a nemzetközi eredményekkel összhangban problémát jelent a százalékszámítás, a kamatos kamat számítása, a legalább, legfeljebb kifejezések kezelése, különböző ajánlatok összehasonlítása.

A digitalizáció terjedésével egyre több elektronikus pénzügyi szolgáltatás érhető el, azonban ezek magasabb szintű, biztonságos használatához szükséges a pénzügyi tudatosság növelése. A pénzügyi adataink megszerzését célzó adathalász sms-ek, e-mailek és az Econventio-teszt egyik 2019-es eredménye, miszerint a középiskolások több mint fele nem tudta, hogy e-mailben nem kérhetnek el webáruházak bankkártyaadatokat, arra is rámutatnak, hogy az ismeretek mellett a digitális pénzügyi eszközök tudatos használatát is tanítani kell. A pénzügyi szolgáltatások, megoldások gyorsütemű fejlődése miatt, a jövőben olyan megoldásokkal is fogunk találkoz- 
ni, amelyek ma még nem ismertek, a jelenlegi oktatásban, képzésekben nem jelennek meg. Emiatt a pénzügyi, gazdasági ismereteink folyamatos fejlesztése, illetve az erre való igényre nevelés is szükséges.

Összességében vizsgálataink alátámasztják a Pénzügyi Tudatosság Stratégia célkitűzéseinek szükségességét. Az elmúlt tíz év alapján megállapítható, hogy a gazdasági ismeretek oktatá- sának hatása van a diákok pénzügyi tudására, tudatosságára, ugyanakkor szükségét érezzük a pénzügyi gazdasági ismeretek gyakorlatias oktatásának, a tudás fejlesztése mellett a készségés attitűdelemek együttes fejlesztését. A mai komplex világban a különböző jártasságok (literacy), kompetenciák (pénzügyi, gazdasági, statisztikai, digitális stb.) együttes, komplex fejlesztésére van szükség.

\section{JEGYZET}

1 A tanulmány elkészítését az EFOP-3.6.2-16-2017-00007 azonosító számú, Az intelligens, fenntartható és inkluzív társadalom fejlesztésének aspektusai: társadalmi, technológiai, innovációs hálózatok a foglalkoztatásban és a digitális gazdaságban című projekt támogatta. A projekt az Európai Unió támogatásával, az Európai Szociális Alap és Magyarország költségvetése társfinanszírozásában valósul meg.

\section{IRODALOM}

Amagir, A., Groot, W., Maassen van den Brink, H., Wilschut, A. (2018). A Review of Financial-literacy Education Programs for Children and Adolescents. Citizenship, Social and Economics Education, 17(1), pp. 56-80, https://doi.org/10.1177/2047173417719555

Atkinson, A., Messy, F. (2012). A pénzügyi kultúra mérése: Az OECD / Nemzetközi Pénzügyi Képzési Hálózata (INFE) kísérleti kutatásának eredményei. OECD Pénzügyi, Biztosítási és Magánnyugdíjpénztári Mühelytanulmányok, 15, OECD Publishing

Beck, J. J., Garris, R. O. (2019). Managing Personal Finance Literacy in the United States: A Case Study. Education Sciences, 9(2), p. 129, https://doi.org/10.3390/educsci9020129
Béres D., Huzdik K. (2012). A pénzügyi kultúra megjelenése makrogazdasági szinten. Pénzügyi Szemle, 57(3), 322-336. oldal

Botos K., Botos J., Béres D., CserNÁK J., Németh E. (2012). Pénzügyi kultúra és kockázatvállalás a közép-alföldi háztartásokban. Pénzügyi Szemle, 57(3), 291-309. oldal

Denis, D. J. (2016). Applied Univariate, Bivariate, and Multivariate Statistics. Wiley, New Jersey

Harputlu, S. M., Kendirli, S. (2019). An Assessment on the Financial Literacy Level of Generation $Z$. In: Uçak, H. (szerk.). Proceedings Book 3rd International Conference on Economic Research, 2425th October pp. 56-61, Alanya, Turkey, ISBN: 978-605-81058-2-9 
Hasler, A., Lusardi, A. (2017). The Gender Gap in Financial Literacy: A Global Perspective. Global Financial Literacy Excellence Center, The George Washington University School of Business

Hogarth, J. M., Hilgert, M. A., Beverly, S. G. (2003). Patterns of Financial Behaviors: Implications for Community Educators and Policymakers. No 883, Proceedings, Federal Reserve Bank of Chicago

Horváthné KöKÉny A., Széles, Zs. (2014). Mi befolyásolja a hazai lakosság megtakarítási döntéseit? Pénzügyi Szemle, 59(4), 457-475. oldal

Huzdik K., Béres D., Németh E. (2014). Pénzügyi kultúra versus kockázatvállalás empirikus vizsgálata a felsőoktatásban tanulóknál. Pénzügyi Szemle, 59(4), 476-488. oldal

Klapper, L., Lusardi, A. (2020). Financial Literacy and Financial Resilience: Evidence from Around the World. Financial Management, 49(3), pp. 589-614,

https://doi.org/10.1111/fima.12283

Klapper, L. F., Lusardi, A., van Oudheusden, P. (2015). Financial Literacy Around the World: Insights from the Standard \& Poor's Ratings Services Global Financial Literacy Survey.

Kovács, L., Terták, E (2019). Financial Literacy, Werlag Dashöffer

Kovács, L. (2018). A pénzügyi kultúra és tudás fejlesztése. In: Pál, Zs. (szerk): FINTELLIGENCE Tudományos Pénzügyi Kultúra Körkép, 39-56. oldal

KovÁcs L., SüTő Á. (2020). Megjegyzések a pénzügyi kultúra fejlesztéséről. Gazdaság és Pénzügy, 7(1), 137-146. oldal, http://doi.org/10.33926/GP.2020.1.6

Kovács P., Kuruczleki É. (2017). A magyar lakosság pénzügyi kultúrája. In: Veresné $S$.
M., Lipták K. (szerk.) „Mérleg és Kihívások” X. Nemzetközi Tudományos Konferencia - „Balance and Challenges" $X$. International Scientific Conference: Konferenciakiadvány: A közgazdászképzés elindításának 30. évfordulója alkalmából. Miskolc-Egyetemváros, Magyarország, Miskolci Egyetem Gazdaságtudományi Kar, 302-309. oldal

Lusardi, A., Hasler, A., Yakoboski, P. J. (2020). Building up Financial Literacy and Financial Resilience. Mind \& Society, pp. 1-7

Lusardi, A., Mitchell, O. S., Curto, V. (2010). Financial Literacy Among the Young: Evidence and Implications for Consumer Policy. CFS Working Paper, No. 2010/09. Center for Financial Studies

Mondres, T. (2019). How Generation $\mathrm{Z}$ is Changing Financial Services. ABA Banking Journal, 111(1), p. 24

Németh E., Vargha B. T., Domokos K. (2020a). Pénzügyi kultúra. Kik, kiket és mire képeznek? Összehasonlító elemzés 2016-2020. Pénzügyi Szemle, 65(4), 554-582. oldal, https://doi.org/10.35551/PSZ_2020_4_7

Németh E., Zsótér B., Béres D. (2020b). A pénzügyi sérülékenység jellemzői a magyar lakosság körében az OECD 2018-as adatainak tükrében. Pénzügyi Szemle, 65(2), 281-308. oldal, https://doi.org/10.35551/PSZ_2020_2_8

Zsótér B., NÉMeth E., Luksander A. (2017). A társadalmi-gazdasági környezet változásának hatása a pénzügyi kultúrára. Pénzügyi Szemle, 62(2), 251266. oldal

MNB - PSZÁF (2008). Együttműködési megállapodás a pénzügyi kultúra fejlesztése területén. Online: https://www.mnb.hu/letoltes/0415mnb 
pszafmegallpodas-penzugyi-kultura-fejleszte.pdf, Letöltve: 2017. szeptember 10.

OECD (2013). PISA 2012 Assessment and Analytical Framework. PISA 2012 Assessment and Analytical Framework: Mathematics, Reading, Science, Problem Solving and Financial Literacy. OECD Publishing

OECD (2015). OECD/INFE Core Competencies Framework on Financial Literacy for Youth. OECD Publishing
OECD (2016). OECD/INFE International Survey of Adult Financial Literacy Competencies. OECD Publishing

OECD (2020a). OECD/INFE 2020 International Survey of Adult Financial Literacy. OECD Publishing

OECD (2020b). PISA 2018 Results (Volume IV): Are Students Smart about Money? PISA, OECD Publishing, Paris 